\title{
ON A GLACIAL CONGLOMERATE IN THE TABLE MOUNTAIN SANDSTONE.
}

\author{
By Arthur W. Rogers, M.A., F.G.S.
}

(Read February 6, 1901.)

During the progress of the Geological Survey in the Clanwilliam Division last year a remarkable conglomerate was found, apparently lying in the Table Mountain Sandstone. The conglomerate is peculiar in containing flattened and striated pebbles scattered through a muddy matrix.

The observations were made on the Pakhuis Pass, over which runs the road from Clanwilliam to Calvinia. The accompanying map and section illustrate the geological features of the locality, and show the position of the outcrops to which reference will be made in the following description.

The conglomerate occurs on a horizon known as "the shale band," on account of its being the thickest and most constant band of argillaceous material in the great arenaceous deposit called the Table Mountain Sandstone. The shale band has been followed more or less continuously from the Hex River Mountains, round the south and west of the Warm Bokkeveld, through the Scurftebergen, Cold Bokkeveld Mountains, and Cederbergen.* The position of the shale band is usually marked by a steep slope at the foot of an escarpment formed by the overlying sandstone, and covered with fragments fallen from it. This feature may be well seen at several places on the west side of the Hex River Valley, and in Mitchell's Pass. The rock itself is very rarely exposed on the slopes or where a gorge or ravine crosses the outcrop, but only in artificial road cuttings. In Mitchell's Pass the part of the shale band exposed on the roadside is a sandy shale, red in colour owing to weathering.

* The shale band was first recognised by Mr. Schwarz in the Hex River and Warm Bokkeveld Mountains. In the 1st Ann. Rep. Geol. Comm. C. G. H. for 1896 , p. 27, he describes two shale bands, one near the top of the Table Mountain Sandstone, and the other near the bottom: the upper of these two is the one referred to above. The course of this band between the Schurftebergen and Pakhuis is described in the 5th Ann. Rep. for 1900. 
On a farm called Bailie's Gat in the southern part of the Cederbergen (in the field-cornetcy Scotland, of the Ceres Division) a bridle-path has been cut across a steep slope made of the shale band; the rock is exposed for some twenty yards along the path, and is a grey or brown shale with red and yellow stains very similar to some of the beds belonging to the Bokkeveld formation. North of the farm Pakhuis a similar rock is seen in a road cutting, and also in a cutting on the main road between Piquetberg Road and Clanwilliam, in the Olifants River Valley. At Bailie's Gat the shale band lies about 1,000 feet below the top of the Table Mountain Sandstone, but further south there seems to be less sandstone above it, although the thickness is difficult to estimate closely, both on account of the varying dip of the beds and the rugged nature of the country. The thickness of the shale band itself is also difficult to estimate, as the exact top and bottom of it are never seen, but it probably varies from 200 to 500 feet.

West of Clanwillian the Table Mountain Sandstone forms a broad anticline trending north-west, and sinking in the same direction, so that the beds dip some few degrees north of north-east, and west of south-west, on the two sides of the axis. Near the village the sandstone is faulted against the Bokkeveld Beds, which form the socalled Karroo hill, but further up the Olifants River it dips normally under an outlier of those beds. Similarly on the north-east side of the anticline, the Bokkeveld Beds have been let down against the sandstone between the farms Hoender Fontein and Welbedacht, while both to the north and south the usual conformable passage between the two formations is met with.

The road from Clanwilliam goes through the farms Klein Kliphuis, Rheebok's Valley, round the south end of Botha's Berg on to the farm Pakhuis. Between the houses on Rheebok's Valley and Pakhuis the road is carried along the curved outcrop of the shale band, and the rock is exposed at intervals through a distance of about three miles and a half. To the north-west of Rheebok's Valley the shale band is marked by a bushy, débris-covered slope, which lies on the north-east side of the Kliphuis River; above the slope is a continuous cliff, which terminates southwards in Botha's Berg. To the north-east of Botha's Berg the shale band sinks into the Pakhuis Valley, where it forms the flat ground on which the farm stands. From Pakhuis the band trends south-east towards Krakadouw, up the Pakhuis River.

The road between Rheebok's Valley and Pakhuis lies on the lower part of the shale band, for outcrops of the underlying sandstone are seen on the hillside immediately below the road near 
Rheebok's Valley, at the summit of the Pass, and on the eastern side of the summit.

About two hundred yards above Rheebok's Valley house the conglomerate is seen in the ditch by the roadside, and also in shallow pits from which road-mending material is dug. The rock is a greenish-brown, sandy, unbedded mud-stone, with abundant wellrounded grains of quartz and a little felspar; pebbles up to five inches in length are contained in it. The pebbles are not arranged in layers, but are scattered through the rock at intervals of several inches or feet, and as the exposures are rather small only a few pebbles of the largest size were found. Since the amount of material removed to make the shelf for the road is not very great, and at the same time consists mostly of surface soil and fallen débris, only a small portion of the underlying conglomerate has been disturbed, so that there are no artificial débris heaps from which specimens of the pebbles can be collected. All the specimens obtained were picked out from the rock in situ, and some of these were only discovered on breaking down large lumps of the mud-stone.

Between Rheebok's Vlei and the top of the Pass there are no more good exposures, but the conglomerate is seen in the ditch by the roadside. Beyond the highest point there are numerous but small excavations along the road, forming a nearly continuous section perhaps two miles long. The bulk of the rock is an unbedded mud-stone with scattered pebbles, similar to that in Rheebok's Vlei; but two important varieties occur, in one of which an approach is made to the usual type of the Table Mountain Sandstone by the great increase of the proportion of quartz grains, and the other furnishes a transition series between the conglomerate: and a shale, such as is seen by the roadside north of Pakhuis and in Bailie's Gat. The shaly variety of the conglomerate is seen about. half a mile from the top of the road. In composition and colour it. is similar to the unbedded rock, from which it differs by the presence of planes of lamination. Parts of this rock contain fewer grains. of quartz than others, and thus assume the character of shale, and become red and yellow when weathered. The dip of the gritty shale is about $10^{\circ}$ towards N., $35^{\circ}$ E., agreeing with that of the quartzite outcrops below the road, and with that of the quartzites in the mountains above. It is only in the shaly portion of the conglomerate that dip can be observed, for in the other sections, none of which is more than 10 feet high, the conglomerate shows no sign of bedding.

The pebbles found in the conglomerate are of quartz, quartzite, dark hard grits, felsites, and granite. Many of them, especially the 
smaller ones, are well rounded; the small, often almost spherical, white quartz pebbles up to an inch in diameter, like those commonly found scattered through every part of the Table Mountain Sandstone, are particularly noticeable, and more abundant than any other sort. Nine pebbles showing signs of glaciation were collected. The largest is $3 \frac{1}{2}$ inches in length, 2 in width, and about 1 inch thick. It is composed of a hard, gritty slate. One surface is almost flat and covered with scratches, which are chiefly in two series, crossing each other at an angle of about $3^{\circ}$; a few other scratches cut across both these sets; the opposite surface is also fairly well striated, but it has been worn down to a smaller extent. One of the edges of the stone is also scratched. This specimen is indeed a typical glaciated pebble. Five of the other pebbles are also characteristic specimens, but smaller in size, the smallest being only $1 \frac{1}{2}$ inches in length. The remaining three only show scratches on a portion of one surface.

The evidence for a glacial origin of the conglomerate, i.e., that ice played an important part in the locality during its formation, rests upon two facts :-

(1) The peculiar character of much of the rock itself, viz., the distribution of large pebbles at intervals through a fine-grained sandy mudstone.

(2) The flattened and facetted form of the pebbles, and their striated surfaces.

In ordinary conglomerates the pebbles are very much more numerous in proportion to the matrix than in the Pakhuis beds, and at the same time they are arranged in layers; generally, too, there is a rough assortment of the stones, so that pebbles of about the same size are found together. The Pakhuis rock is best compared to glacial deposits, such as the Dwyka conglomerate of this country or some of the tills of the northern hemisphere.

In the absence of any observed unconformity at the base or top of the Pakhuis beds they may have been deposited in water, like the sandstones above and below; the shaley portions certainly were, and as unstratified sandy clays with ice-born fragments are admitted to have been formed under water in recent times, there is no sufficient reason to assume terrestrial conditions in the locality during the formation of the unbedded part of the Pakhuis conglomerate.*

When the conglomerate was first observed its points of resemblance to the Dwyka conglomerate immediately attracted attention. The similarity consists in the scattered striated pebbles being embedded

* Feilden, "Glacial Geology of Arctic Europe," \&c., Q.J.G.S., vol. 1., 1896, p. 739 . 
240 Transactions of the South African Philosophical Society.

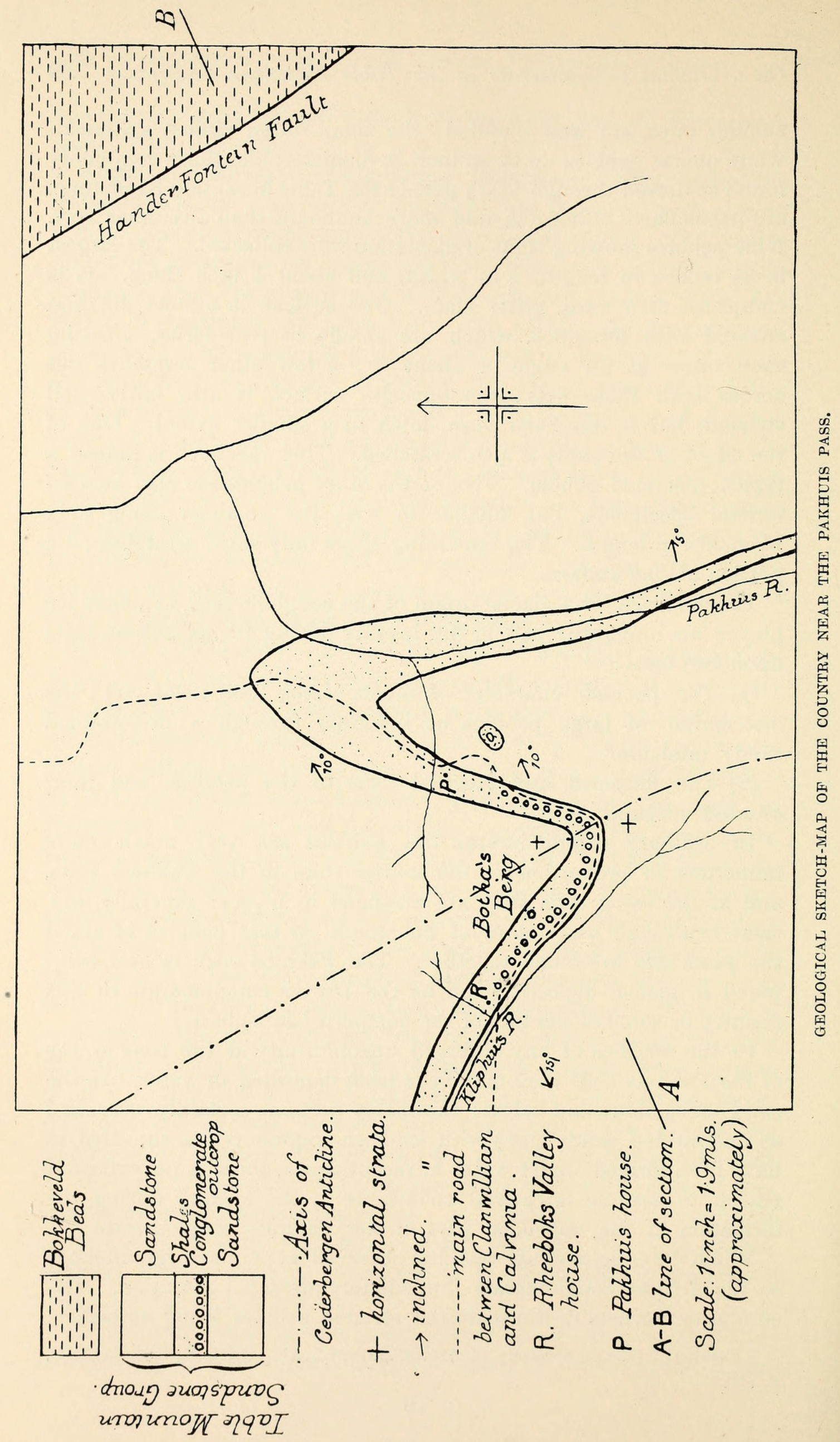


On a Glacial Conglomerate in the Table Mountain Sandstone. 241

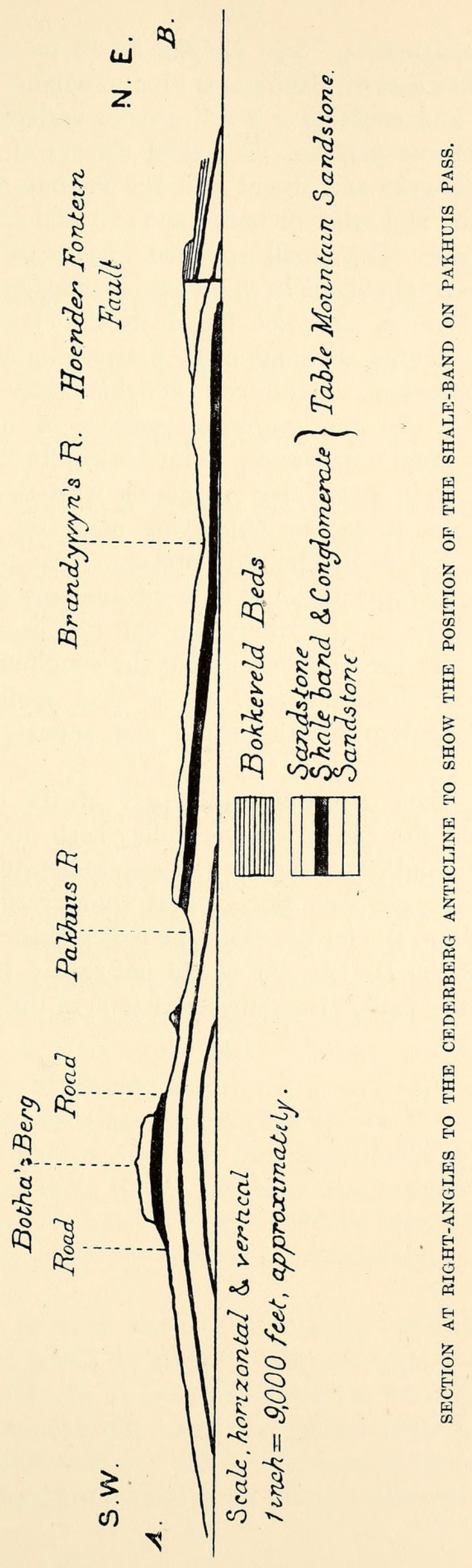


in a fine-grained matrix. The Dwyka found in the Karroo, some twenty-five miles east of Pakhuis, is blue in colour, harder than the Pakhuis rock, and contains a much greater variety of rocks in the form of boulders or pebbles. The chief classes of rocks which are present in the Dwyka and absent from the Pakhuis conglomerate are the amygdaloidal and other diabases, and amygdaloidal rocks of more acid composition. The small rounded quartz pebbles, mentioned above as being so abundant in the Pakhuis conglomerate and Table Mountain Sandstone, are not found in the Dwyka. There is, however, no essential distinction at present known between the lithological characters of the two conglomerates; therefore the determination of the stratigraphical position of the Pakhuis conglomerate is of great importance. The description of the occurrence of the conglomerate given above, together with the position of the outcrop laid down in the accompanying map and section, contains all that can be said on this point at present. The parallelism of the conglomerate outcrop with those of the sandstones above and below, and the agreement in dip, where dip can be observed in the conglomerate, lead to the conclusion that the conglomerate is actually interbedded with the sandstone, but a clear section showing the conglomerate overlain by the shale and sandstone will be very welcome.

I have been over a considerable part of the country between the Karroo and the Olifants River valley both north and south of Pakhuis, but no outlier of the Dwyka conglomerate has been found there; and as on the east side of that country the Bokkeveld and Witteberg Beds, or the former alone, lie between the Table Mountain Sandstone and the Dwyka, one would not expect the Dwyka to lie directly upon the Table Mountain Sandstone in the Cederbergen. 


\section{$2 \mathrm{BHL}$ Biodiversity Heritage Library}

Rogers, Arthur W . 1900. "ON A GLACIAL CONGLOMERATE IN THE TABLE MOUNTAIN SANDSTONE." Transactions of the South African Philosophical Society 11, 236-242. https://doi.org/10.1080/21560382.1900.9525969.

View This Item Online: https://www.biodiversitylibrary.org/item/113791

DOI: https://doi.org/10.1080/21560382.1900.9525969

Permalink: https://www.biodiversitylibrary.org/partpdf/175448

\section{Holding Institution}

Field Museum of Natural History Library

\section{Sponsored by}

The Field Museum's Africa Council

\section{Copyright \& Reuse}

Copyright Status: NOT_IN_COPYRIGHT

This document was created from content at the Biodiversity Heritage Library, the world's largest open access digital library for biodiversity literature and archives. Visit BHL at https://www.biodiversitylibrary.org. 